\title{
Rosja i jej mieszkańcy w oczach polskich jeńców wojennych XVII oraz początków XIX wieku
}

Tomasz Ślęczka 


\section{nAPIS Seria XIII 2007}

\section{Tomasz Ślęczka}

\section{Rosja i jej mieszkańcy w oczach polskich jeńców wojennych XVII oraz początków XIX wieku}

\section{Wstęp}

$\mathrm{H}$

istoria stosunków polsko-rosyjskich doczekała się znacznej liczby opracowań, pochodzących od autorów reprezentujących różne dyscypliny naukowe; także i zagadnienie oglądı państwa carów oczami polskich i litewskich żołnierzy ma dość obfitą bibliografię . Zamysłem niniejszego artykułu jest ukazanie sposobu, w jaki polscy pamiçtnikarze-żołnierze, walczący na wschodzie w siedemnastym wieku oraz wojnie 1812 roku, opisywali Rosję i jej mieszkańców, kiedy zdarzyło im się na dłużej popaść w moskiewską niewolę. Utworów tych nie jest wiele - trzy pochodzą z siedemnastego stulecia, zaś kolejne cztery dotyczą kampanii 1812 roku. Naturalnie nie jest mym zamiarem wyciąganie z zestawienia tych kilku dzicłek dalej idących wniosków - zbyt wątla to podstawa materiałowa, by kusić się o formułowanie wniosków ogólniejszej natury. Niemniej zarys obrazu, jaki uzyskamy, wart jest - jak mniemam — choćby naszkicowania.

Stanisław Niemojewski (ok. 156()-1620), autor chronologicznie najstarszego pamiętnika, był członkiem starej rodziny szlacheckiej, starannie wykształcony, około 1603 roku osiągnął godność podstolego wielkiego koronnego. Rok 1606 zastał go w Mos-

\footnotetext{
1 Z dostępnych opracowań poświęconych wspomnieniom polskich jeńców w Rosji wypada wymienić przynajmniej dwa - pracę Mieczyslawa Wieliczki, Jeniectu'o wojeme Polakón w' Rosji w' latach 1503-

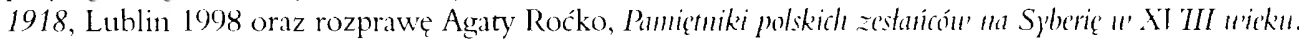
Olsztyn 2001; pierwsza z nich to jednak przede wszystkim antologia tekstów, druga zaś clironologiczne „rozmija się” z zakresem omawianym w niniejszym artykule.
} 
kwie, gdzie przywiózł klejnoty przeznaczone dla cara Dymitra. Kiedy car został zamordowany, Niemojewski trafił od moskiewskiej niewoli, w której przebywał do 1609 roku. Po powrocie osiągnął godność kasztelana elbląskiego, później zaś chełmińskiego. O jego wspomnieniach tak pisał Władysław Czapliński:

Pamiętnik ten $[\ldots]$ jest ciekawy po pierwsze ze względu na przedstawienie stosunków panujących na dworze Samozwańca i opis przewrotu, potem ze względu na dokładny i ciekawy opis Rosji, wreszcie jako pierwszy chyba w paniętnikarstwie polskim opis życia w obozie jeniecko-więziennym².

Michał Leon Obuchowicz wywodził się ze stosunkowo dawnej, bo poświadczonej już w XV wieku, rodziny szlacheckiej, osiadlej w okolicach Nowogródka na Litwie. Pamiętnikarze (rodzina wydała ich bowiem aż trzech) zamieszkiwali powiat mozyrski na Polesiu. Michał Leon (ok. 1630-1669), autor interesujących nas wspomnień z moskiewskiej niewoli, odebrał edukację w Akademii Wileńskiej, następnie osadzony został na królewskim dworze, przebywając tam jako dworzanin pokojowy; towarzyszył monarsze podczas pobytu na Sląsku. W 1656 roku rozpocząl karierę wojskową w wystawionej przez ojca chorągwi kozackiej, później dowodził pułkiem w wojsku litewskim. W trakcie walk z Moskwą powierzano mu znaczące funkcje w armii, podczas jednej z potyczek na początku 1660 roku został ranny i dostał się do niewoli. Na uwolnienie oczekiwał w stołecznej Moskwie wraz z wieloma innymi znacznymi jeńcami (między innymi hetmanem polnym Wincentym Gosiewskim), doczekał się go dwa lata później. Reszta życia upłynęla naszemu pamiętnikarzowi na udziale w walkach z Moskwą oraz w życiu publicznym.

O powstaniu pamiętników piszą autorzy Wstępu:

Michał Leon Obuchowicz swe wspomnienia spisywał w dwu turach - po raz pierwszy po powrocie z niewoli moskiewskiej w 1662 roku i to ona stała się głównym obiektem jego zainteresowania. Bez wątpienia jednak w trakcie pobytu w Moskwie czynił stosowne notatki, które stanowiły następnie źródło wiedzy i osnowę wykładu. [...] Po raz drugi sięgnął po pióro, notując przeżycia związane z wyprawą na Rosję na przełomie 1663 i 1664 r., być może od razu zdając sobie sprawę z jej historycznego znaczenia. Ostatecznie tekst $w$ formie pamiętnika spisał jednak bodaj dopiero w końcu 1664 lub w samym początku 1665 r..$^{3}$

\footnotetext{
2 W. Czapliński, Wstęp w: J. Ch. Pasek, Pamiętniki, opr. W. Czapliński, Kraków 1979, s. 20.

3 H. Lulewicz, A. Rachuba, Wstẹp w: Pamiçtniki Filipa, Michuta i Teodora Obuchouiczón' (1630-1707), red. A. Rachuba, Warszawa 2003. S. 22 :tto://rcin. org. pl
} 
Również w 1660 roku, tyle że podczas bitwy nad Basią, do moskiewskiej niewoli trafił Adam Kamieński z przydomkiem Dłuzyk (ok. 1635 - ?) szlachcic z Orszy (a zatem Litwin), wrócić z niej przyszło mu dopiero około 1671 roku; podczas jenieckiej tulaczki przemierzył ogromme polacie Syberii, walcząc w wojsku moskiewskim przeciw mieszkającym tam ludom: jego wspomnienia ${ }^{+}$uznawane są za wiarygodne. Jak pisze Mieczyslaw Wieliczko:

losy polskiego jeńca tego czasu, które opisał A. Dłuzyk-Kamieński, są nie tylko pierwszym polskim pamiętnikiem syberyjskim, ale szczególnej wartości świadectwem jeniectwa w Rosji w połowie XVII wiekus.

Pierwszym z zajmujących naszą uwagę dziewiętnastowiccznych dzieł są pamiętniki Ignacego Lubowieckiego'. Ich autor (1782-1837) uczęszczał do szkoły w Zamościu, studiował prawo we Lwowie, następnie zdecydował się na karierę wojskową, odbierając edukację w Wiedniu. W 1805 roku, po stronie austriackiej, brał udział w bitwic pod Austerlitz, w roku 1807 wstąpił do tworzącej się armii Księstwa Warszawskiego, do powstającego 2 pułku ułanów, jako oficer tej jednostki trafił w 1812 roku do moskiewskiej niewoli. Pamiętnik spisał u schylku zycia, i była to juz jego trzecia wersja (dwie poprzednie zaginęly w 1812 oraz 1831 roku).

Stanisław Małachowski (1770-1849), fundator 14 pulku kirasjerów w roku $18(19$, członek bardzo wpływowej i zasłużonej rodziny szlacheckiej, był jeńcem rosyjskim w latach 1812-1814. Jego relacja o niewoli w Rosji znalazla się w dwu odrębnych tekstach - rękopiśmiennej relacji ${ }^{7}$ oraz w 31 pisanych po francusku listach do żony, nigdy niewyslanych.

Trzeci z pamiętników wyszedł spod pióra Melchiora Witkowskiego", urodzonego w 1793 syna leśniczego. Pamiętnik pod względem literackim nie stanowi wielkiego osiągnięcia, jednak z uwagi na wiele interesujących spostrzeżeń uznawany jest za cenne źródło poznania dziejów szeregowych żołnierzy, którzy popadli w rosyjską niewolę. Podobny los co Witkowskiego spotkat innego piszącego podoficera - Stanisława Nowackiego", którego z kolei jeniecki los rzucil do Gruzji"."

+ A. Kamieński Dłużyk, Diariusz wiczicnia moskicuskiego, miast i miejoc, oprac. A. Kuczyński, B. Polewoj, Z. J. Wójcik, w: Dura polskic pamiętniki z Sy'berii XI II i XT III wick, red. A. Kuczyı́ski. Warszawa-Wroclaw 1996.

"M. Wieliczko, Jeniecturo wojeme' Polakóu'..., op. cit.. s. 23.

"I. Lubowiecki, Panrictmiki, oprac. N. Kasparek, Lublin 1997.

S. Małachowski. Opis urzieccia mego un nicu'olę dnia 18 listopada 1812 rokm. Poznań 1885.

* M. Witkowski, Pamiçtuik prostego sotniera = lat 1812-1816, w: Pamictmiki = hat 1792-1849, oprac. R. Grabowski, Wroclaw 1961.

"S. Nowacki, Podráże do Georgii u' cadsie mojej nicuroli u' Rosyi odlyyte u' roku 1813, 1814i 1815. Poznań 1833.

"' Szczegółów jego biografii nie udało mi się dotąd ustalić, nie odnotownje go również Polski Ston'nik Biograficzn'. 
Okazjonalnie przyjdzie nam sięgnąć do tekstów innych autorów, którzy bądź w ogóle w moskiewskiej niewoli się nie znaleźli, bądź też przebywali w niej krótko, przywołania te będa jednak incydentalne, na celu mając wylącznie lepsze ukazanie pewnego konkretnego zjawiska.

\section{Trafianie do niewoli}

Do niewoli trafiało się na ogół wskutek pochwycenia podczas walki, najczęściej pamiętnikarze wskazują na swój zacięty opór oraz odniesione liczne rany. Chronologicznie najstarsza relacja (Stanisława Niemojewskiego) zawiera wywód autora, który w ogóle nie uznaje swego jenieckiego statusu, wskazując na niebojowy charakter popadnięcia w niewolę. Argumentuje, iz do Moskwy trafił jako legalny wysłannik na dwór legalnego monarchy, który to monarcha został przez wiarołomnych poddanych zamordowany, zaś sam poseł pochwycony przez buntowników i przetrzymywany bez jakiejkolwiek podstawy prawnej; był więc jeńcem wojennym szczególnego rodzaju.

Kolejny z autorów, Michał Obuchowicz, okoliczności popadnięcia w niewolę relacjonuje krótko. Wspomina o powierzeniu mu przez hetmana wielkiego litewskiego dowództwa nad zbrojną ekspedycją, o bitwie z Moskalami, w której wróg miał znaczną przewagę, o wycofaniu się niektórych chorągwi, głównie dragońskich. W walce

okrążony od Moskwy, kilkam ciężkich ran ponióst - jedną w twarz in conflictu, drugie w głowie trzy, już gdym konia zbył ${ }^{\prime \prime}-$

zamyka całą wypowiedź. Podobnie oszczędną relację daje Adam Kamieński, wspominając jedynie, iz

wzięty byłem w roku 1657 dnia 20 Oitobra w potrzebie kiedy z kniaziem Juryim Dolchorukiem, pod Basią między Uchtami była potrzeba [... $]^{12}$.

Ignacy Lubowiecki do moskiewskiej niewoli trafił 25 października 1812 roku. Stało się to podczas walki z kozakami, mającymi — jak podaje pamiętnikarz — czterokrotną przewagę. Wspomina:

Pierwszy więc chcąc sobie pałaszem otworzyć drogę, rzuciłem się wśród kozaków, i tam otoczony będąc zewsząd, padł koń pode mną skaleczony i ja zalany krwią własną na ziemię, odniósłszy pikami i pałaszami ran jedenaście ${ }^{13}$.

M. L. Obuchowicz, op. cit., s. 287.

12 A. Kamieński Dłużyk, op. cit., s. 13. W tekst rękopisu wkradł się błąd, gdyż bitwa nad Basią miała miejsce trzy lata później.

.3. Lubowiecki, op. cit., s. 138. 
Żywego podniesiono go z pola walki, widząc w nim francuskiego generala (powodem pomyłki miało być podobieństwo jego podpułkownikowskich dystynkcji do generalskich, stosowanych w armii rosyjskiej). Oczywiście został ograbiony, co odnotowuje bez emocji jako rzecz zwyczajną i do obyczaju wojemnego należącą; następnie porzucono go między konającymi, szczęśliwie został odnaleziony i uratowany.

Aleksander Fredro do niewoli dostał się jako chory, przebywający w szpitalu (o czym wszakże bezpośrednio w swym pamiętniku nie wspomina): analizując jednak samo zjawisko „dostawania się do niewoli” czyni przy tym niezwykle cickawą uwagę, rzucającą pewne światło na jego postrzeganie wroga - w tym przypadku byli nim kozacy. Pisze mianowicie:

Byłem w niewoli u Rosjan, i to w chwili, gdy do zemsty niemało mieli powodów. Moskwa spalona, część kraju w puszcze zmieniona [...] Sławianie pastwić się nie umią, nie znają nieprzyjaciela, jak tylko z bronią w ręku. Kozacy, zwłaszcza starzy, obdarłszy pierwej, to się rozumie, i przeciągnąwszy raz nahajem, byli potem dla jeńców z tym poszanowaniem [...], a którego Niemcy zupełnie nie rozumią. Kozak uderzył i dwa razy nahajem, jeżeli zdobycz nie odpowiadała jego nadziei. — Co ty za oficer, kiedy nie masz zegarka! — Ale bili bez litości, jeżeli przy wziętym w niewolę znaleźli co z cerkiewnych rzeczy ${ }^{1+}$.

I jego więc sam rabunek nie dziwi, zaś samo wspomnienie o popadnięciu w niewolę staje się okazją do analizy charakteru poszczególnych nacji, z którymi polskim żołnierzom przyszło się zmierzyć — i w tej swoiście rozumianej „rywalizacji” Rosjanie wypadają najkorzystniej.

Melchior Witkowski do niewoli trafial dwukrotnie. Za pierwszym razem stało się to bez większego uszczerbku na zdrowiu, o okolicznościach zresztą specjalnie się nie rozpisuje, wskazując na fakt, iż walczył podczas odwrotu, wielı innych zginçło, a wielu (w tym i jego) Moskale pobrali. Nadmienia — również bez śladu emocji —

Odebrali mi wszystko odzienie i tornister ze wszystkim, nawet i płaszcz wzięli ze mnie, i jeszcze kilka bizunów dostałem od nich $[\ldots]^{15}$.

W trakcie przemarszu udało mu się zbiec, usiłował wrócić w rodzinne strony, jednak po dłuższych perypetiach został ujęty i znowu trafił między jeńców"l. Podobny los spotkał Nowackiego — i on, wpadlszy w niewolę, zbiegł z niej, jednak po krótkim epizodzie uciekinierskim trafił na powrót w rosyjskie ręce ${ }^{17}$.

\footnotetext{
+ A. Fredro, Trzy po trzy, w: tenze, Pisma uszystkic, oprac. S. Pigoń, t. 13. Warszawa 1968, s. 42.

${ }_{15}$ M. Witkowski, op. cit., s. 26.

"Zob. ibidem. s. 42.

17 S. Nowacki, op. cit., s. 5.
} 
Stanisław Małachowski popadł w nie 18 listopada 1812 roku, podczas odwrotu Wielkiej Armii, kiedy to odłączony od towarzyszy wpadl na znaczny oddział kozaków. Dzięki śmialej odpowiedzi udało mu się nawet uchronić od rabunku, mimo iż „pospolicie pieniądze i wszystko, co ma jeniec, zabierają" ${ }^{18}$. Jednak utracił wszystkie bagaże, zawierzając obietnicy kapitana Popowa, że zostaną mu niezwłocznie odesłane. Jak konkluduje, nie znał się jeszcze wtedy na prawach rabunku, zaś obietnica została dotrzymana ,z restrykcyją jezuicką" ". Wniesione zażalenie do dowódcy, generała Ilowajskiego XII, spotkała się jedynie z rozbawioną odprawą.

\section{Los jeńca}

\subsection{Strażnicy}

Relacje jeńców z ich strażnikami stanowią kwestię złożoną. Nie wszyscy nasi aıtorzy stykali się z brutalnością straży — zresztą jej postępowanie najpewniej zależało od miejsca przetrzymywania, statusu społecznego jeńców oraz aktualnej polityki rosyjskiej - Obuchowicz na pilnujących nie narzeka (w ogóle zresztą niewiele o nich wspomina $)^{20}$, podobnie niewiele zlego ma do oznajmienia Małachowski, zauważa nawet, że mimo iż wiedli go prymitywni żołnierze, Baszkir i Tatar, znośniejsi byli niż wielu innych, polerowniejszych. Również Kamieński nie rozwodzi się specjalnie nad swymi strażnikami, wspominając jedynie o bardzo przykrym zabezpieczeniu, jakie Moskale stosowali, utrudniając jeńcom ucieczkę - nasz pamiętnikarz został przykuty do działa na kilka dni, także później, podczas przemarszu na wschód, jeńcy zostali skuci²1. Lubowiecki z kolei opowiada o dwu rodzajach eskorty, którym podlegat. Najpierw, tuż po popadnięciu w niewolę, ponieważ przeżył, wyznaczono mu miejsce pobytu - miasto Kaługę oraz przydano eskortę, złożona z małomównych, groźnie wyglądających Kałmuków (,z małymi oczami, ponurymi twarzami szerokimi, wypukłym czołem"22 - dorzuci jeszcze pamiętnikarz). Później, kiedy to po zniknięciu francuskiego zagrożenia Rosjanie powrócili do Kaługi (gdzie ciężko chorego porzucono go uprzednio na pastwę losu1), z jeńców sformowano tyınczasowe oddziały i wysłano w głąb imperium. Jedyne złe słowa, jakie Lubowiecki ma do powiedzenia o straznikach, dotyczą dowodzącego eskortą chorążego, przez którego większość jeńców zmarła podczas przemarszu. Po drodze jeńcy masowo chorowali na „zaraźliwą gorączkę", dowódca odmawiał leczenia aż do chwili, kiedy sam na nią zapadł; dla wielu

\footnotetext{
S. Malachowski, op. cit., s. 115.

"' Ibide'm, s. 116.

" Co nie musi budzić zdziwienia - jako ważna osoba Obuchowicz był traktowany znacznie lepiej niż jego mniej dostojni towarzysze walki.

21 A. Kamieński Dłużyk, op. cit., s. 13 i nast.

"Ibidem, s. 1+1.
} 
jeńców było już jednak za późno. Również prosty kapral Witkowski ma wiele do powiedzenia o niegodziwym postępowaniu dowodzącego wiodącą go eskortą kapitana, która jednak manifestowała się nie w przyczynianiı sic̨ do wymierania nieszczęsnych prowadzonych, a w prywatnym bogaceniu się. Relacjonuje mianowicie, jak to przedsiębiorczy kapitan rozmyślnie prowadził kolımnę bocznymi drogami, by rozpowiadać mieszkańcom mijanych wsi, że wiedzie okrutników jednookich, którzy zjadają dzieci, jednak za rozsądną opłatą może ich zabrać i poprowadzić dalej, nie ząadając noclegu w tejże wiosce. Na ogół uzyskiwał pewne korzyści materialne (jak konklıduje pamiętnikarz - „Mial natenczas surdut ciemnozielony, i to jeszcze zly do tego, kiedy nas odebrał w Bałchowie, a potym sobie lisy sprawił i bryczkę krytą z szybowanymi kołami"23). Sprawiedliwość jednak zwyciężyla, jako że po dotarciu na miejsce przeznaczenia jeńcy złożyli skargę na niegodziwego kapitana, który został ukarany. Nowacki o eskorcie w zasadzie nie wspomina, zapewne nie miał jej nic do zarzucenia, może teź pewne dolegliwości uznawał za nieuniknione. Jak widać, przytoczone powyżej zdanie Fredry, wysoko oceniającego postępowanie Rosjan z jeńcami, wydaje się na tle pozostałych relacji odosobnione. Jeżeli już bowiem pamiętnikarze mają coś dobrego do powiedzenia o Rosjanach-strażnikach, to dzicje się to wyłącznie w zestawieniu z jeszcze gorszym postępowaniem innych nacji (najgorzej oceniano niewolę u Prusaków).

Jak się wydaje, w materii relacji: jeńcy — pilnujący, niewiele się przez stulecia zmieniło; narzekania na niegodziwych strażników dręczących jeńców obecne są we wspomnieniach i z wieku XVII, i XIX (te z wieku XIX są liczniejsze, ale i więcej mamy samych relacji), w tej materii niewiele się zresztą zmieniło po dziś dzień.

\subsection{Miejsce uwięzienia}

Jeńców przetrzymywano w różnych miejscach, których charakter nie zmienił się przez stulecia, korzystano bowiem z tych samych, sprawdzonych rozwiązań. Najlepszy był - jak się zdaje — los Obuchowicza, któremu dane było przebywać w Moskwie, w stosunkowo znośnych warunkach. Słuszne powody do narzekania miał natomiast Niemojewski, któremu przypadł los zesłaníca - trafił wpierw do Rostowa, a następnie aż do Białego Jeziora, i w takich terminach przyszło mu żyć ponad dwa lata. Spośród dziewiętnastowiecznych pamiçtnikarzy podobny los spotkal Lubowieckiego — osadzono go w Tambowie, gdzie przyszło mu spędzić niemal półtora roku. Znacznie gorzej potraktowano jednak szeregowych oraz podoficerów - tych bez pytania wcielano do armii carskiej i wysyłano w odległe rejony imperium, na ogół na Kaukaz — co stało się udziałem Nowackiego (choć Witkowski trafil do Omska, a zatem na Syberię). Po-

${ }^{23}$ M. Witkowski, op. cit., s. 50 ). 
dobne przygody czekały Kamieńskiego, którego carska wola rzuciła na dalekie rubieże Syberii.

Praktyka przetrzymywania jeńców w odległych rejonach państwa ma za sobą dlugą tradycję, nie sposób zresztą odmówić jej pewnej racjonalności - zwłaszcza w sytuacji, kiedy jeszcze trwa wojna i zachodzi niebezpieczeństwo odbicia jeńców przez ich rodaków. Naturalnie z punktu widzenia tak traktowanych mowa może być wyłącznie o udręczeniu, nie o racjonalności.

\section{Lokalne realia w oczach uwięzionego}

\subsection{Ceremonie religijne}

Uwięzieni dokonują obserwacji różnej natury, zwracają też uwagę na kwestie natury religijnej. Przeważają relacje z obserwowanych ceremonii, choć poszczególnych autorów interesują one w nierównym stopniu, zapewne zależy to od indywidualnej wrażliwości. Odmienny bywa też wydźwięk tych opowiadań, nie zawsze bowiem mamy do czynienia z obiektywnym opisem innych zwyczajów, czasem dochodzą bowiem do głosu emocje. Wydaje się także, iż wraz z upływem czasu słabnie zainteresowanie opisywaniem obrzędów religijnych — wśród pamiętnikarzy wieku XIX wzmianki o uczestnictwie - choćby biernym - należeć będą do rzadkości.

Najbardziej emocjonalna jest relacja Niemojewskiego. Ciekawią go obyczaje religijne; odnotowuje wstępowanie popów w stan małżeński, informuje, że po utracie żony pop staje się zwyczajnym chłopem, że po trzecim ślıbie świeckiego dopuszcza się jedynic do sakramentu spowiedzi, że poród w domu plami go i trzeba go oczyszczać. Konklızja ujawnia jednak nastawienie pamiętnikarza:

Takich i inszych blędów siela u tych głupców i wyrodków dawnego świętego kościola greckiego, którzy za nieposłuszeństwem jako od jedności odpadli, nie mając jednego pasterza i dyrektora, wiarę świętą i obrzędy kościelne w superstycyje obrócieli $[\ldots]^{24}$.

Dodaje też, że szczególną nienawiść budzi u miejscowych religia rzymska, zaś najgorszą obelgą jest „Bodaj ty beł łatynnikiem!”” ${ }^{2}$. Wyśmiewa również ceremonie, związane z obchodami święta Trzech Króli. Pod adresem duchowieństwa prawosławnego nie ma nic dobrego do powiedzenia, pisząc, iż ich argumentacja teologiczna stoi na niezwykle niskim poziomie, uzasadnia:

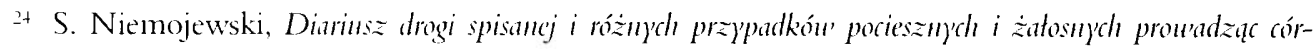
ke Jerzego Mniszka, Marn'ng, Dy'mitrou' In'anou'iczou'i u' roku 1606, oprac. R. Krzywy, Warszawa 2006, s. $1+3-1+4$.

25 Ibidem, s. $1+4$. 
O racyje też na insze rzeczy spytasz li ich, odpowie-ć: „Tak siç w naszej ziemi wiedzie i taki obyczaj”. Tak to ćwiczeni i nczeni teologowie ${ }^{26}$.

Nie sposób jednoznacznie rozstrzygnąć, na ile ta postawa względem prawoslawia jest wynikiem osobistych przekonań autora, z jakimi do Rosji juz przyjechał, być może bowiem nabył ich dopiero podczas swego ıwięzienia, niechęć do Rosjan przenosząc automatycznie i na ich religię.

Znacznie bardziej tolerancyjny jest Obuchowicz, zresztą jako Litwin z natury rzeczy żywszy musiał mieć kontakt z prawosławiem, niektórzy z jego współwięźniów z pewnością byli tej konfesji, z wieloma innymi na pewno slużył w wojsku litewskim, spotykał się w domu, w działalności cywilnej lub na forum publicznym. Dwie relacje dotyczą obchodów "ruskiej Kwietnej Niedzieli”27 w 1660 oraz 1661 roku. Poza zwięzłym opisem ceremonii z zaciekawieniem odnotowuje fakt, iz podczas carskiego przejazdı żołnierze całymi oddziałami padali na twarze: opis tej sceny nie stał się jednak okazją do rozważań nad niewolniczym charakterem imperium carów, nie znać też w relacji pogardy wobec tego zwyczaju, tak obcego polskiej obyczajowości. Spośród odmicnności odnotowıje różnicę kalendarzy, wskazıjąc na fakt obchodzenia przez „naszych" uroczystości Wielkanocy pod tą samą datą. Kolejna relacja dotyczy ceremonii chrzczenia wody (15 stycznia 1662). Pamiętnikarz dość dokładnie ujmuje cały obrzęd, a opisując postacie, podkreśla przede wszystkim bogactwo strojów, wskazuje na obecne osoby, żadnych krytycznych uwag równiez i tym razem nie czyni.

Adam Kamieński niewiele uwagi poświęca opisowi prawosławnych ceremonii religijnych, uwage swoją koncentrując raczej na kultach pogańskich, z którymi przyszło mu się zetknąć. $Z$ pewnym rozbawieniem odnotowuje praktykę Moskali, polegającą na obdzieraniu czczonych przez Wogulców posążków bóstw z cennych futer, składanych im w ofierze ${ }^{28}$, zauważa też swoistą karę, zsyłaną na świętokradców przez obrażonych „szatanów”. Opisując mieszkające na wschodzie ludy, zazwyczaj kilka słów poświęca na ich określenie religijne, nie wnikając jednak w same kulty i kontentując się ogólnikowymi określeniami pokroju „poganie i bałwochwalcy, czarownicy, z diabłami w zmowie".

W pamiętniku Lubowieckiego brak relacji o uczestnictwie w jakichkolwiek ceremoniach religijnych; może nie był zbyt religijny, moze też nie uważał za stosowne o tym pisać - tego nie wiemy. Jedynym religijnej natury odniesieniem jest jego przypuszczenie, iż większość ludności, zamieszkującej Tambow i okolice. jest pochodzenia tatarskiego, poparte dowodem, iż ludzi ci, wychodząc z domu, zwykli każdorazowo

2t Ibidem, s. 276.

${ }^{27}$ Zob. M. L. Obuchowicz, op. cit., s. 291 i nast.

28 A. Kamieński Dłużyk, op. cit., s. 22. 
obmywać dłonie w specjalnym naczyniu; Lubowiecki widzi w tym pozostałości tradycji muzułmańskiej.

Stanisław Małachowski wspomina o szczególnym przywiązaniu narodu rosyjskiego do religii (w nieposzanowaniu cerkwi widząc nawet jedną z przyczyn ruszenia się ludności przeciw Francuzom - rzekomo wielu Rosjan było skłonnych przylączyć się do nich, jednak ich obchodzenie się z miejscami kultu pchnęło potencjalnych buntowników do walki przeciw najeźdźcom), posuniętym nawet do zabobonu i fanaty$z^{2 m{ }^{24}}$. Informuje o wielości cerkwi w miastach, jak również wyraża swój podziw dla ich estetycznych walorów. Wysoko ocenia też postępowanie prawosławnych duchownych - ich przestawanie wyłącznie we wlasnym gronie, nieuczestniczenie w życiu towarzyskim, aprobuje ich utrzymywanie przez rząd. Uważa, iż kapłan powinien być albo wyłącznie sługą Bożym, albo wylącznie obywatelem. Kończąc opis, konkluduje:

Jak długo księża nie zostaną zwykłymi obywatelami, potęga kapłańska będzie połączoną zawsze ze szkodą naszego spoleczeństwa i religii ${ }^{30}$.

Podoba mu się również hieratyczna powaga podczas nabożeństw, aprobuje brak ławek w katedrze (,nie ma lawek, w których u nas nieraz się usypia” 31 ), do przekonania trafia spokojny i zwięzły sposób głoszenia kazań, brak maniery retorycznej oraz spektakularnej gestykulacji. Podoba mu się równiez śpiew kościelny. W aprobującym tonie pisze również o zwyczaju przechodniów pozdrawiania się oraz całowania podczas drugiego duia Wielkanocy; wiele sobie po tym obiecywał, wychodząc na przechadzkę i wypatrując atrakcyjnych, młodych niewiast - oczywiście trafiła mu się jedynie pomarszczona staruszka ${ }^{32}$. Biorąc pod uwagę, że adresatką listów miała być żona, można w taki przebieg wydarzenia nieco powątpiewać. Wspomina również szczególny sposób sprawowania spowiedzi, przypadającej na pierwszy tydzień Wielkiego Postu. Pop ma zwyczaj spowiadania ludu w ten sposób, że z fizjonomii osądza, jaki rodzaj grzechu popełnil jej właściciel, następnie pyta, czy popełnił taki grzech, zapytany odpowiada prosto „tak lub nie”, przeważają odpowiedzi twierdzące. Prosty lud widzi w tym natchnienie Ducha Świętego, Malachowski jednak zauważa, że namiętności targające ludzką duszą są po pierwsze odwieczne, po wtóre wspólne wielı ludziom, zatem i grzechy popełniają podobne. Zauważyl też, iż po zakończeniu jednego z uroczystych nabożeństw arcybiskup wyczytał listę zdrajców i przeklętników, wśród nich Kościuszkę i Bonapartego, co wcale mu się nie spodobało.

O świątecznym calowaniu się wspomina również Nowacki, naturalnie w tonacji aprobującej; o wlasnych doświadczeniach w tej materii wprawdzie milczy, jednak

Zob. S. Małachowski, op. cit., s. 134.

3in Ibidem, s. 153.

Ibide'm.

32 Zob. ibide'm, s. 155. 
można się między wierszami doczytać śladów pewnej satysfakcji. Ponadto w dziełku Nowackiego można znaleźć wiele informacji o życiu religijnym nacji muzułmańskich, zamieszkujących Kaukaz — chociaż spostrzeżenia natury religijnej nie są w jego panniętniku zbyt częste. Jedyna anegdota o treści religijnej dotyczy opowieści o nawiedzonej cerkwi w Astrachaniu, w której co noc, okolo północy, słyszano szczękanie łańcuchów oraz potępieńcze wycia - czego nie wytrzymywali psychicznie nawet strażnicy i często w panice opuszczali posterunek. Rzecz całą wyjaśnił dopiero odważny Polak-strażnik, który nie przeląkł się całej tej makabrycznej otoczki i śmialo wszedł do wnçtrza świątyni; okazało się, iż wszystkie te budzące grozę odgłosy były wynikiem świadomie prowadzonej przez szajkę miejscowych złodziei działalności maskującej — w opuszczonej cerkwi zwykli oni bowiem kryć swe lupy, bezpieczni dzięki złej sławie miejsca ${ }^{33}$.

Witkowski z kolei wspomina o udziale w obrzędach Wielkiego Tygodnia, jednak nie wdaje się w szczególy, traktując najwyraźniej rzecz całą jako oczywistą i nie wymagającą dogłębnicjszego opisu; od czasu do czasu wtrąca jedynie osobliwe szczególy - na przykład iż podczas procesji katolicy chodzili w prawo, zaś „schizmatycy w lewo" 3 .

\subsection{Wrodzona kłamliwość Moskali}

W relacjach wszystkich pamiętnikarzy ( $n b$. nie tylko jeńców) uderza wielokrotnie powtarzana refleksja nad wrodzonym przywiązaniem Moskali do kłamstwa (w życiu prywatnym oraz relacjach międzypaństwowych). Niemojewski formułuje najdalcj chyba idący wniosek, wspominając, jak to Moskale ludzili jeńców nadzieją, że skoro zginąl Samozwaniec, to nie ma powodów, by Polaków trzymać w zamknięciu, i lada dzień nowy car poleci ich uwolnić. Jak jednak konkluduje,

na czem-eśmy się barzo omyleli, jeszcze świadomi nie będąc, żeby to tak klamliwy naród beł, jakośmy z nieszczęściem naszym doznali, bo nie tylko żeby się kłamstwa (tak sprośnego grzechu i sromoty) wystrzegać mieli, ale owszem, sami się jakoby tym chełpią, i kiedy któremu rzecze, .Żeś płonną rzecz powiedzial" — naprzód przysięgać się będzie na krzyż święty, żegnając się, twierdząc to, co powiedzial, a jako go dońdzie, że przecie inaczej jest, niż on twierdzi, na ostatek przyzna się i bez wszelakiego zapłonienia rzecze: „Zełgał ja”. A ten zwyczaj zachowuje się między przedniejszymi, nie tylko między pospólstwem. Jeden też drugiemu zadać takie kłamliwe słowo - sromoty żadnej nie masz ${ }^{35}$.

\footnotetext{
33 Zob. Nowacki, op. cit., s. 85.

${ }^{3+}$ M. Witkowski, op. cit., s. 45.

35 S. Niemojewski, op. cit., s. 115-116.
} 
W innych miejscach wielokrotnie wspomina, jak to polscy jeńcy byli ustawicznie zwodzeni przez cara i jego urzędników.

Również Obuchowicz wielokrotnie skarży się na „moskiewską chytrość, ustawiczne dążenie do oszukania drugiej strony, o uzyskania jej kosztem jak największych korzyści. Jedna ze scen, przez którą manifestuje się moskiewskie mijanie się z prawda, nie utraciła zresztą po dziś dzień swej aktualności. Relacjonując mianowicie początek praktyki zaniżania przez Moskali racji żywnościowych, która to sytuacja miała miejsce po 3 września 1661 roku, Obuchowicz notuje wypowiedź jednego z nadzorców, który opowiedzial uwięzionym o różnych nieprawościach, jakich hetman Czarniecki miał się dopuścić na trzymanych u siebie poddanych cara, oraz oświadczył, że

i carskie wieliczestwo, slysząc o takowych nieprawdach i niechrześcijańskich postępkach waszych, każe wam karmu ubawić i w Kałmyki zasłać, ponieważ i Czarniecki tak skazał, że gdy na pewnym terminie okup za ludzi moskiewskich nie przyjdzie, do I Iordy ma ich zaprzedac ${ }^{36}$.

W innym miejscu pamiętnikarz scharakteryzuje tę praktykę (którą miał przecież okazję naocznie obserwować), pisząc o wypowiedzi innego Moskala:

Co szyroce, podług zwyczaju swego, nieprawdę naszę coraz powtarzając... ${ }^{37}$.

Później okazało się dowodnie,

że tak nie jest w samej rzeczy; a zatym aby powieści moskiewskie w konfuzyi zostały ${ }^{33}$.

Jak widać, argument, że złe postępowanie strony moskiewskiej ma słuszną i uzasadnioną przyczynę w jeszcze gorszych postępkach strony polskiej, ma za sobą długą i znacznie dawniejszą, niż byśmy to mogli sądzić, tradycję. I równie jest zgodne z prawdą.

W innej sytuacji, wspominając o głodzie wywołanym kolejnym obniżeniem „stawki żywieniowej", znajduje jednak racjonalne uzasadnienie całej sytuacji, wskazując na drożyznę oraz powszechny niedostatek pożywienia, jaki zapanował w całej stolicy państwa carów; nadmienia jednak, że pilnujący nieskłonni byli się do tego przyznać, i zgodnie ze swoim obyczajem kłamliwie wywodzili, że i ich rodacy w polskich rękach cierpią glód oraz wykorzystywani są do ciężkich prac ${ }^{34}$.

3t M. L. Obuchowicz, op. cit., s. 301.

3. Ibidem, s. 296.

38 Ibide'm, s. $3(1) 3$.

34' Zob. ibidem, s. 307. 


\subsection{Poziom umysłowy ludności miejscowej}

Pośród rozmaitej natury uwag, formułowanych na temat rosyjskich realiów. znajdujemy (skądinąd mało szczegółowe) dygresje, poświęcone ocenie poziomu umysłowego ludności miejscowej. Często uwagi takie przybierają postać kategorycznych stwierdzeń; odnieść wręcz można wrażenie, że kwestia ta nie wymaga nawet uzasadnienia, że rozumie się sama przez się. Niekiedy jednak natrafić możemy na fakty lub anegdoty, uzasadniające niezwykle niską ocenę Rosjan w oczach Polaków czy Litwinów.

Niemojewski często posługuje się epitetami typu „barbarus” czy „naród gruby”, na ogół nie idąjednak za tym żadne dowody, czasem jednak obdaruje czytelnika jakimś szczegółem. Odnotowuje na przykład zupełny brak wiedzy mieszkańców w kwestiach narodowościowych - znają ich bowiem tylko trzy: najwspanialszą wlasną, potem litewską (mianem tym obdarzają łącznie i Litwinów, i Polaków), wreszcie niemiecką, uznając istnienie Niemców duńskich, Niemców francuskich, Niemców szwedzkich, Niemców brabanckich. Po dwustu latach wiedza ta niespecjalnie się poszerzyla, bowiem miejscowa ludność w każdym obcym zwykła widzieć Francuza, o czym zaświadczają autorzy ówczesnych pamiętników; do rzadkości należy rozpoznawanie innych nacji.

Wspomina, że często się żegnają, poszczą niemal połowę roku, natomiast nauczania praktycznie nie ma, czytać nie wolno ani posiadać ksiąg - poza psałterzem i kazaniami św. Jana Chryzostoma - Moskale widzą w tym niebezpieczeństwo, że taki człowiek chce być mądrzejszy niż car. Identyczne wyjaśnienie da w tej materii również Maskiewicz. Godzi się przypomnieć, że Niemojewski był jednak do Rosjan bardzo uprzedzony.

Imiennik Niemojewskiego, Nowacki, nie wyraża wprost niewysokiej oceny, jaką wystawiłby umysłowości carskich poddanych, jednak niekiedy między wierszami da się dojrzeć takie przekonania. Opowiadając o powrocie z Kaukazu do Polski wspomina krótki pobyt u kozaków dońskich, mówi wtedy, iz przyjemnie można porozmawiać jedynie z tymi kozakami, którzy powrócili z wojny, podczas niej bowiem nabrali pewnej ogłady i stali się lepszymi kompanami niz ich niebiorący udziału w walkach rodacy. Mając na uwadze wszystkie oceny, jakimi obdarzano kozaków podczas wojny, trudno takie nabywanie ogłady uznać za komplement ${ }^{+1}$. Przy okazji wspomina nasz autor o problemie, jaki stał się udziałem powracających w domowe pielesze weteranów - wątpili (podobno zasadnie) w wierność swych żon, co stało się powodem wiclu niesnasek. 


\subsection{Miejscowe obyczaje}

Kwestia odmienności moskiewskich obyczajów pojawia się rzecz jasna na kartach interesujących nas pamiętników, jednak poszczególni autorzy zwracali uwagę na rozmaite sprawy - zależało to od wielu czynników, tak osobistych, jak i wynikających z charakteru miejsca, w którym przyszło im przebywać.

Niemojewski jest względem miejscowych bardzo krytyczny. Zauważa częste wtrącanie w mowie urągań „od matki”, które miejscowi traktują jako coś zwyczajnego, nie widząc w takiej praktyce nijakiej obelgi. Wspomina o powszechnie akceptowanej sodomii, o rozwiązlości w życiu, przy jednoczesnej obecności najróżniejszych przesądów oraz uznawania za grzech spraw trzeciorzędnych, jak spanie bez pasa, brak krzyżyka na szyi czy golenie brody. Informuje, że brak jest praw spisanych (co akurat nie odpowiada prawdzie), sądy sprawowane są wylącznie wedle prawa zwyczajowego, a idea neminem capti'abimus... miejscowym wydaje się dziwna i nienaturalna. Zauważa, że jedzą inaczej, cielęciną się brzydzą, zbytku w pożywieniu unikają, potrawy mają grube i niesmaczne. Piją najchętniej gorzalkę, także białogłowy. Opisuje również ubiór, sposób chodzenia, budowania, zauważa brak luksusowej broni (jedyne egzemplarze zostały zdobyte na Polakach). Na weselach nie używają muzyki ani tańców, jedynie pija. Na drogę piją za zdrowie kniazia, patriarchy itd., a kto zmyli kolejkę, jest juz podejrzany.

O szacunku carskich poddanych dla swego pana ma świadczyć opowiedziana anegdota, kiedy to na czytanie publiczne pisma carskiego miejscowi zdjęli czapki, żądając tego samego od Polaków; ci odpowiedzieli hardo:

Byle co pociesznego usłyszeć do odpuszczenia nas, nie tylko czapkę zdejmiem, ale i niższe odzienie opuściem ${ }^{41}$.

Respons mało kulturalny, jednak uzasadniony okolicznościami, w jakich został wygłoszony - wlaśnie zmniejszono im racje żywnościowe o jedną trzecią.

Polscy jeńcy wielokrotnie korespondowali z carem, pisemnie żaląc się na swój los i prosząc o jego polepszenie (listy tego rodzaju zajmują sporą część tekstu pamiętnika), Car jednak odpowiadał niechętnie i rzadko. Niemojewski wywodzi stąd następujący wniosek:

To nieodpowiadanie i nierychle się w każdej rzeczy rezolwowanie - wszytkim pólnocnym narodom ten bydlęcy obyczaj zwyczajny, a nie dziw, bo tak każdy małego rozsądku i dowcipu miałkiego, zaczym ubroń Boże każdego z nimi sprawy, a szczęśliwy, który nie doświadczywszy, cudzym się przykładem karać będzie. O, Boże mój, czemuś mi też tego szczęścia nie dał² 
Uwagi dotyczące moskiewskiej obyczajowości u Obuchowicza rozsiane są po kartach pamiętnika, nie tworząc zwartej i zamkniętej całości, poświęconej tej jednej kwestii. Przy różnych okazjach autorowi zdarza się zauważyć, że w danej sytuacji u Moskwy w zwyczaju jest czynić... Z przypadkowości jednak tego rodzaju uwag wolno chyba wnosić, że nie obserwacje natury etnograficzno-kulturowej stanowily dla podkomorzego mozyrskiego kwestię pierwszej wagi.

Dowiadıjemy się więc, że sposobem wyrażania radości jest bicie w dzwony — jak to miało miejsce w dniu 9 czerwca 1661 roku, po narodzinach carewicza Fiedora. Informuje również, że przysyłanie potraw oraz trunków powszechnie uznawane jest za wyraz sympatii ${ }^{+3}$. O potrawach niewiele ma do powiedzenia - na ogół wskazıje na ubóstwo pożywienia, raz jednak, opisując jedną z uczt, na którą zaproszono więźniów do księcia Dołgorukiego, krytycznie pisze o potrawach, iż „dość w liczbie [...] było, ale rzadka nie spaskudzona” Znakiem szczególnego szacunku wobec gościa miało być również powitanie go nie przez samego gospodarza, ale przez jego żonę wraz z ofiarowaniem poczęstunku $\mathrm{ku}^{+5}$.

Pamiętnik Witkowskiego z kolei jest źródłem wielu interesujących szczegółów obyczajowych, nierzadko bardzo egzotycznych, jako że dane mu było przewędrować przez niemal cale imperium rosyjskie, poznając (choćby pobieżnie) życie i obyczaje różnych narodów tworzących to państwo. Były kapral nie jest jednak obserwatorem zbyt ciekawym, zresztą i charakter obserwacji determinowany jest przez jego pozycję społeczna - tym, co go najbardziej interesuje, są obyczaje niższych warstw społecznych, odmienne sposoby gospodarowania, inne niz znane $z$ domu metody radzenia sobie z niesprzyjającą przyrodą, inne sprzęty gospodarskie. Ciekawsze są kaukaskie notatki Nowackiego, który zapisuje nawet micjscowe legendy, jak choćby podanie o chłopie-czarnoksiężniku, który odjął miejscowym wężom cały jad. Zbyt wiele tych jednak obserwacji, by je literalnie wymieniać.

Cenniejszym — bo pochodzącym od znacznic lepiej wykształconego autora — źródłem na temat poznania realiów syberyjskich jest diariusz Kamieńskiego. W sposób płynny i foremny litewski jeniec prowadzi czytelnika przez syberyjskie bezdroża, obszernie i szczególowo opisując egzotyczne z jego punktu widzenia ludy, ich zwyczaje, oraz wplatając w wartki tok narracji opowiadanie o własnych losach. Również i w tym przypadku nie sposób przeprowadzić wnikliwszej analizy spostrzeżeń nieszczęsnego żołnierza znad Basi.

Ignacy Lubowiecki o odmiennych obyczajach nie wspomina prawie wcale (poza obmywaniem rąk), jednak nie ma w tym nic dziwnego - caly czas pobytu w Tambowie spędził w gronie miejscowej elity, ta zaś - będąc z natury rzeczy kosmopolityczna

4.3 Zob. M. L. Obuchowicz, op. cit., s. 311.

+t Ibidem, s. 317.

t5 Zob. ibidem, s. 318. 
— obyczaje miała wszędzie dość podobne. Zresztą w ogóle relacja podpulkownika Lubowieckiego jest uboga w szczególy i zazwyczaj bardzo powściągliwa.

Małachowski w jednym miejscu paniętnika gromadzi i systematyzuje swoje obserwacje natury socjologiczno-obyczajowej. Dostrzega urodę ludu rosyjskiego, wysoki wzrost, siłę i zdrowie. Negatywnym tlem jest dla niego polska wiés - przyczynę powszechnego na niej skarlenia widzi w masowym pijaństwie. O Rosjanach - co ciekawe i niezwykle rzadkie - ma dobrą opinię, widzi w nich nację mało pijącą. Sąd ten wydaje się jednak odosobniony. Powodem niskiego spożycia alkoholu jest też jego zdaniem brak żydowskich karczm w rosyjskich wsiach. Pijanych widıje się rzadko, w użyciu jest przede wszystkim kwas oraz wrzątek z rozpuszczanym w nim miodem.

Pozytywny jest również sąd Małachowskiego o poziomie higieny — widzi wszędzie czystość, zauważa masowe korzystanie z grzebieni oraz łaźni, których jest wiele. Odnośnie stanu chłopskiego autor posuwa się wręcz do stwierdzenia:

chłop tutejszy, chociaż więcej na pana pracujący, chociaż więcej podatków placący, chociaż nawet imię niewolnika noszący, jest szczęśliwszy niż u nas. W izbie jego nie widać takiej nędzy $[\ldots]$ bogatszy jest od naszego, odzież jego jest czyściejsza i lepsza, żywność cechę nędzy nienosząca ${ }^{\text {th }}$.

Odnotowuje zwyczaj sprzedawania ludzi, ale widzi i pozytywy — liczne i dobrze prowadzone zakłady dla podrzutków.

Podobnie jak Niemojewskiego uznać przyszło za obserwatora uprzedzonego, tak z kolei Małachowski wydaje się obserwatorem nazbyt entuzjastycznie nastawionym do miejscowych realiów, by przyjąć jego relację bona fide.

Podsumowując, pochodzących z różnych epok autorów interesują więc podobne sprawy - choć oczywiście w odmienny sposób i w odmiennym natężeniu, nie bez znaczenia okazuje się również poziom umysłowy samego pamiętnikarza.

\subsection{Refleksje ekonomiczne}

Kwestie natury gospodarczej na ogół nie zaprzątały uwagi naszych jeńców, z wylączeniem zagadnień związanych z przydzielanymi im racjami żywnościowymi. Narzekanie na zbyt ubogie wyżywienie wspólne jest zresztą pamiętnikarzom z obu interesują̧cych nas epok. Poza jednak kwestię „,ile rubli na dzień” autorzy nasi na ogół nie wychodza, kontentując się co najwyżej podkreślaniem „bogactwa” lub „ubóstwa” regionu, w którym przyszło im przebywać.

Jedynym wyjątkiem jest tu Niemojewski. Moskali wprawdzie nie lubi, jednak nie wpływa to na trzeźwość sądu oraz glębię spostrzeżeń. Zastrzega się wprawdzie, 
że tyle uwagi poświęca sprawom natury ekonomiczno-militarnej jedynie dlatego, by czas niewoli nie okazał się czasem zupełnie zmarnowanym, spostrzeżenia jego mają jednak walor znacznic głębszego osądu, dalej idących refleksji; nic są to w żadnym razie pobieżne, przypadkowo rzucane uwagi.

Podstawową cechą jest poszukiwanie źródeł (głównie finansowych) potęgi państwa carów. Niemojewski dostrzega je w clach i podatkach, w tych ,intratach”, jakie skarb carski wybiera z poszczególnych przedsięwzięć ekonomicznych. Jednym z takich źródel, bardzo obfitym, jest monopol alkoholowy. Jak pisze pan Stanisław,

z tego Kazania i Astrakania przedniejsza intrata wielkiemu kniaziowi przychodzi, która ledwie nie wszytka z warzenia piwa a kurzenia gorzatek idzie ${ }^{7}$.

Łączny dochód z samych znajdujących się w tamtym regionie Rosji browarów i gorzelni szacuje na 80 tysięcy złotych. Wylicza również inne przychody — cła (choć z uwagi na niewielki rozmiar handlu nie przynoszą zbyt duzych dochodów), kary i grzywny, opłaty i inne podatki (na przyklad spadkowy). Dalej wylicza intraty z innych ziem państwa rosyjskiego (choć na ogół nie posiłkując się liczbami — zapewne ich nie znał), łącznie szacując je na zbliżone do kwoty 50() tysięcy złotych polskich. Niemojewski wylicza też wydatki, które car musi ponosić - jego rozważania zmierzają więc prostą drogą do szacunkowego obliczenia budżetu cara.

Ponieważ ze sferą ekonomiczną silnie związana jest sfera militarna, Niemojewski omawia to zagadnienie zaraz po analizie kwestii gospodarczych. Wylicza, z jakich jednostek złożona jest armia moskiewska, w jaki sposób są one rekrutowane, kto i ilı żołnierzy jest obowiązany wystawić, analizuje też stosunkowo wówczas nowe rozwiązanie, jakim byla formacja strzelców. Informuje, w jaki sposób prowadzone są działania wojenne. Wojsko moskiewskie ocenia dość wysoko, zdecydowanie niżej ceniąc wschodnią sztukę fortyfikacyjną — twierdz obronnych w Rosji właściwie nie ma (poza Moskwą i Smoleńskiem), zaś istniejące obwarowania innych miast na ogól nie spełniają swej funkcji, o ile w ogóle istnieją. Co ciekawe, żadnych wniosków dla własnego państwa, żadnych propozycji zmian czy też reform nasz pamiętnikarz nie czyni.

\section{Zakończenie - podsumowanie}

Kończąc, wypada zauważyć, że mimo upływu prawi dwu stuleci, obraz państwa carów, widziany oczyma polskich jeńców wojennych, nie uległ wielkim przemianom. Moskwa jest krajem wrogim, odmiennym tak pod względem religii, jak i obyczaju, którego mieszkańcy mają swoje wady i zalety (choć tych drugich dostrzega się znacznie muiej).

47 S. Niemojewski, op. cit., s. 172. 